\title{
PROSPECTS OF THE DEVELOPMENT OF ALTERNATIVE POWER ENGINEERING IN THE KHERSON REGION
}

\author{
Oleksandr SKLIAROV \\ Taras Shevchenko National University of Kyiv, Ukraine \\ skliarovolexandr@gmail.com
}

\begin{abstract}
One of the most urgent problems of independent Ukraine is energy security and sustainable and efficient of using the energy. Today, Ukraine is an energy-dependent country that has problems with gas supply and environmental condition, which suffer significant deterioration as a result of irrational nature management. Therefore it is appropriate introduction of alternative power engineering as ecologically safe and economically profitable diversified branch of production. The purpose of the research is to determine the territorial differentiation of alternative power engineering sources on the example of the Kherson region - the most potential for the region and prospects of electroenergy in the region. In the article uses the benefited typical general (analysis, synthesis, induction, deduction) and concrete scientific (mathematical, statistical, literary, systematic approach, mapping, forecasting, modeling) methods. Among the results of the research can be distinguished creating maps of perspective placement of alternative power plants; construction a potential fields gravity districts to the most powerful power nodes and settlements; determining regularities of foreign investment for localization.
\end{abstract}

Key words: alternative power engineering, project finance, investment, the "green economy", "green rate", the potential of the territory.

UDC: 911.3

\section{ПЕРСПЕКТИВИ РОЗВИТКУ АЛЬТЕРНАТИВНОЇ ЕНЕРГЕТИКИ У ХЕРСОНСЬКІЙ ОБЛАСТІ}

\author{
Олександр СКляРОВ
}

Київський начіональний університет імені Тараса Шевченка, Україна

skliarovolexandr@gmail.com

\begin{abstract}
Анотація: Однією з найбільш актуальних проблем незалежної України $\epsilon$ енергетична безпека держави та раціональне й ефективне використання отриманої енергії. На сьогодні, Україна $\epsilon$ енергозалежною державою, яка має проблеми із газопостачанням і екологічним станом, що зазнає значного погіршення внаслідок нераціонального природокористування. Через це доцільним $\epsilon$ впровадження альтернативної енергетики як екологічно безпечної та економічно вигідної диверсифікованої галузі виробництва. Метою дослідження $\epsilon$ визначення територіальної диференціаціїальтернативнихджерел енергії на прикладі Херсонської області - найбільш потенційного для цього регіону і перспектив розвитку електроенергетики регіону. У статті використано типові загальнонаукові (аналіз, синтез, індукція, дедукція) і конкретно-наукові (математичний, статистичний, літературний, системний підхід, картографічний, прогнозування, моделювання) методи дослідження. Серед результатів дослідження можна виділити створення картосхеми перспективного розміщення альтернативних енергетичних станцій; побудову поля потенціалів тяжіння районів області до найпотужніших енергетичних вузлів та пунктів; визначення закономірності іноземного інвестування за локалізацією.
\end{abstract}

Ключові слова: альтернативна енергетика, проектне фінансування, інвестиції, «зелена економіка», «зелений тариф», потенціал території.

удк: 911.3

Вступ. Постановка наукової проблеми. У наш час значні кошти виділяються на альтернативні джерела енергіі, до яких відносять сонячну, вітрову та енергію біопалива. Зараз частка електроенергетики у господарстві Херсонщини складає $20 \%$, серед яких лише $3 \%$ займають відновлювальні джерела енергії. Застосування альтернативних джерел енергії все більше поширюється у розвинених країнах Західної Свропи та США, де попит на альтернативну енергію має стійку тенденцію до зростання. Це пов'язано з обмеженістю ресурсів для отримання енергії із традиційних джерел, постійним подорожчанням паливно-енергетичних ресурсів, необхідністю охорони довкілля, наявністю доступу до дешевих джерел виробництва енергії. Визначення та вивчення нетрадиційних

(C) О. Скляров відновлювальних джерел енергії, розвиток альтернативних видів енергоресурсів та перспективу їх використання доцільно розглядати як один 3 головних факторів розвитку енергетики України. Проблеми енергетичної безпеки та розвитку альтернативної енергетики набувають все більшої актуальності та потребують пошуку ефективних шляхів їх вирішення, визначають завдання та окреслюють нові перспективи піднесення енергетичної сфери [5].

Аналіз останніх досліджень і публікацій. Аналіз останніх досліджень і публікацій з даної проблеми показав, що питання інвестування та розвитку альтернативної енергії в Україні розглядалося рядом вчених, таких як: М. Безуглий, М. Волков, Е. Гутнік, I. Магідович, Г. Калетник, А. Касич та низка інших. Разом 3 тим, незважаючи на значний обсяг наукових праць, питанню міжнародного досвіду інвестування 
розвитку альтернативної енергетики не приділялося значної уваги [6].

Формулювання цілей статті. Постановка завдання. Метою даної роботи $є$ аналізування сучасного стану альтернативної енергетики Херсонської області, прогнозування потенціалу вітрової, сонячної та енергії біопалива 3 впровадженням новітніх технологій та залучення іноземних інвестицій.

Виклад основного матеріалу. Глобальні процеси в сучасному світі, зростання світового промислового виробництва, призводять до значного збільшення споживання енергоресурсів i, як наслідок - нанесення суттєвої екологічної шкоди світовому довкіллю. В останні роки ця проблема все більше хвилює світову спільноту, оскільки людині для і1і життя необхідне максимально чисте навколишнє середовище. Тому, в даний момент є підстави вважати екологічні проблеми одними 3 найважливіших для забезпечення майбутнього сталого розвитку людства, саме ці проблеми несуть найбільшу загрозу для світової спільноти.

Україна не залишилась на узбіччі сучасних процесів в енергетиці. Наразі, в нашій країні також 3 кожним роком набирає обертів процес використання альтернативних видів енергії. I хоча процес розвитку відновлювальних джерел енергії відбувається достатньо повільно, не все в цьому питанні безнадійно [2].

Вперше на законодавчому рівні в Україні було дано визначення терміну нетрадиційні i поновлювальні джерела енергії в Законі України «Про енергозбереження» від 1 липня 1994 року. Це енергія, яка постійно існує або періодично виникає в навколишньому середовищі в якості потоків енергії сонця, вітру, геотермальної енергіï, енергії морів, океанів і біомаси. Закон визначив правове регулювання, яке застосовується до юридичних і фізичних осіб котрі проводять роботу 3 будівництва i реконструкції обєктів відновлювальної енергетики [12].

Проте включення електроенергетичної галузі у законодавство не виділяло окремо альтернативні джерела енергії. Через це, у 2003 році було прийнято Закон України «Про альтернативні джерела енергії», яким визначено правові, економічні, екологічні та організаційні засади використання альтернативних джерел енергії та сприяння розширенню їх використання у паливно-енергетичному комплексі. Законом визначено, що альтернативні джерела енергії - це відновлювані джерела енергії, до яких належать енергія сонячна, вітрова, геотермальна, енергія хвиль та припливів, гідроенергія, енергія біомаси, газу з органічних відходів, газу каналізаційно-очисних станцій, біогазів, та вторинні енергетичні ресурси, до яких належать доменний та коксівний гази, газ метан дегазації вугільних родовищ, перетворення скидного енергопотенціалу технологічних процесів [10].

На нашу думку актуальною є проблема створення та впровадження відновлювальних джерел енергії у промислових значеннях. Найбільш важливими стимулами для розвитку відновлювальної енергетики у Херсонській області, в першу чергу, $\epsilon$ обмеженість запасів вітчизняних енергоресурсів та погіршення стану навколишнього середовища. Більшість енергоносіїв надходить до України 3-за кордону, тому ситуація вимагає негайного вирішення питання щодо заміни органічного палива на інші види. Широкомасштабне освоєння енергії відновлювальних джерел створює нову екологічно безпечну галузь енергетики, що сприяє підвищенню рівня диверсифікації енергоресурсів та зміцненню енергетичної й екологічної безпеки держави. Для поліпшення стану альтернативної енергії потрібно проаналізувати найважливіші чинники серед яких виділяються географічний, екологічний, економічний, господарський, політичний та соціальний.

Для розвитку альтернативної енергетики, в першу чергу, потрібна територія та специфічні природні умови. Тому, найбільш важливим чинником серед усіх треба зазначити саме географічний. Йому належить провідна роль у впровадженні енергії відновлювальних джерел у Херсонській області. Частина Херсонської області, що прилегла до Чорного моря, розташована на Причорноморській низині, має рівнинний рельєф, сприятливий для будівництва вітрових електростанцій (надалі ВЕС) на базі вітрових електроустановок (ВЕУ) будьяких габаритів i великих за площею сонячних електростанцій [1].

Вітрова картина на території Херсонської області, особливо в i причорноморській частині, визначається кількома чинниками:

- північно-східними вітрами, які утворюються в результаті руху повітря із зони високого тиску, що 3'єднує Азіатський та Азовський максимуми, й зони низького тиску над Чорним морем;

- південно-західними вітрами, що дмуть також переважно взимку та навесні із Середземного моря;

- західними вітрами, які віють 3 Атлантичного океану, головним чином влітку;

- локальними вітрами - бризами (віють влітку та восени) [13].

Як зазначалося вище, для будування ВЕС та CEC потрібні значні за площею території: площа Херсонської області становить 28500 км², а їі частка, що має високий вітроенергетичний потенціал, -

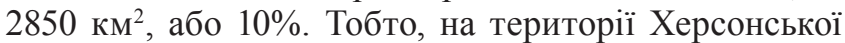
області можливо побудувати вітрові електростанції із загальною кількістю ВЕУ - 2192, номінальною потужністю 2 МВт кожна. Загальна встановлена потужність ВЕУ складатиме 4385 МВт.

He поступається вітровій енергетиці за потужностями й сонячна. За своїм «сонячним» потенціалом Херсонська область посідає одну 3 перших позицій у державі: кількість сонячних днів на рік сягає 240, або 65\%. Одним із показників поширення сонячної радіації є середня сонячна інсоляція, яка на території області становить 1,25 МВт/м² за рік, яка дає значні можливості перспективного розвитку саме сонячної енергетики.

Проте треба враховувати і глобальні проблеми, серед яких важливою $є$ проблема забруднення 
навколишнього середовища. У наш час екологічний стан навколишнього середовища зазнає різкого погіршення: постійні викиди шкідливих речовин, збільшення радіаційного фону та забруднення повітря леткими речовинами, - проте впроваджуючи нові технології в електроенергетиці, що не шкодитимуть екології дуже потрібно. Насамперед це стосується екологічної чистоти виробництва електроенергії з відновлювальних джерел.

Розвиток альтернативної енергетики пов'язаний iз отриманням фінансових доходів. Тому, дуже важливим $є$ економічний аспект цієї проблеми. Застосування альтернативної енергії допоможе: заощадити на виробництві енергії (безкоштовна сонячна радіація та потоки вітру); зменшити необхідність диверсифікації постачання енергії в області; замінити потужності Каховської ГЕС із застарілим обладнанням; розширити номенклатуру продукції підприємств області шляхом замовлення сучасних установок відновлювальної енергетики; децентралізувати постачання електроенергії, що сприятиме суттєвому підвищенню іiі стійкості та зменшенню втрат у процесі передачі на значні відстані; створити незалежність виробництва електроенергії 3 відновлювальних джерел від імпортних поставок палива [7].

Збільшення потужностей альтернативної енергетики буде впливати на розвиток промислових підприємств Херсонської області. Електроенергетика на Херсонщині не дуже розвинута порівняно 3 іншими областями i тому потребує збільшення потужностей. Це можливо, приваблюючи промислові підприємства, а саме на Херсонщині завершено будівництво заводу 3 виробництва біодизельного палива. Потужність підприємства - 10 тис т на рік, паливо планується виготовляти 3 рапсового масла та інших рослинних масел. У лютому 2007 року компанією «Лібер» введено в дію завод в Херсонській області потужністю 10 тис т біодизеля на рік. Крім компанії «Лібер» енергетичні потужності створює і ВАТ «Чумак»: підприємство завершило впровадження реконструйованих під спалювання лушпиння соняшникового насіння (відходи від виробництва соняшникової олії) котлів. Проектна потужність складає - 100000 Гкал/рік [4].

У зв'язку із останніми політичними подіями Україна стала на курс євроінтеграції. Як відомо, у березні 2014 року була підписана Угода про асоціацію між Україною та ЄС. В одному з розділів асоціації розкривалося питання про збільшення потужностей енергії відновлювальних джерел: збільшити частку альтернативної енергії до 12\%. Наразі частка в Україні складає близько 3\%, а тому кожна адміністративна область повинна збільшувати потужності для того, щоб приєднатися до європейських стандартів [9].

Проте, при розвитку будь-якої галузі промисловості, потрібно проаналізувати наслідки для подальшого життя населення. Збільшення потужностей альтернативної енергії може покращити соціальні умови життя населення в області: створити робочі місця на об'єктах відновлювальної енергетики, розвивати інфраструктуру в місцевостях області, віддалених від великих промислових центрів, збільшити надходження до місцевих бюджетів від продажу електроенергії.

На жаль, усі чинники, що перераховані вище, не можуть бути застосовані через відсутність фінансування. Окремим пунктом фінансування потрібно виділити інвестування. У світовій практиці вже давно існує такі поняття, як «зелена» економіка i «зелений» тариф, що позначають розвиток альтернативної енергетики та спеціальні тарифи на постачання енергії до споживача. «Зелений» тариф - спеціальний тариф, за яким йде закупівля електричної енергії, що вироблена на об'єктах електроенергетики, з альтернативних джерел енергії [11]. «Зелена» економіка згідно доповіді ЮНЕП (програма $\mathrm{OOH} з$ навколишнього середовища) - це економіка з низькими викидами вуглецевих сполук, яка ефективно використовує ресурси і відповідає інтересам всього суспільства. В «зеленій» економіці зростання доходів і зайнятості забезпечується державними та приватними інвестиціями у ті заходи і проекти, які сприяють зменшенню викидів вуглецю та забруднення, підвищують ефективність використання енергії i ресурсів, працюють на упередження втрати біорізномаїття та екосистемних послуг. Ці інвестиції необхідно каталізувати та підтримувати шляхом цільових державних видатків, субсидій і стимулів для сприяння розвитку зелених секторів та ринків для зелених технологій та інновацій [5].

Дуже важливо проаналізувати як саме здійснюється інвестування в альтернативну енергетику. Найкращим механізмом інвестування $€$ проектне фінансування - це така структура запозичень, повернення коштів при якій базується на першочерговому використанні накопичених проектом грошових потоків, а всі активи, права й вигоди виступають як коштовні папери вторинного ринку та, у свою чергу, використаються як забезпечення [3].

Вже на 2015 рік іноземні інвестори виявили інтерес до виробництва альтернативної енергетики. Серед усіх проектів можна виділити будівництво трьох електростанцій 3 потужністю 8 MBт чеською компанією «Чеська перспектива Херсон», «Херсонобленерго» в Генічеському (потужністю 75 МВт) і Новотроїцькому районах (32 МВт), а також поблизу Херсона (60 МВт). Згідно проектного фінансування вже завершене будівництво декількох електростанцій: енергопостачальними компаніями «Соларенерго» у Скадовському (27 МВТ), «Сивашенергопром» у Чаплинському (5 МВт), «Бі Енерджетікс» i «Віндкрафт» у Каланчацькому (39 МВТ), «Старпівденьенерго» у Каховському (1,5 МВт) та «Атлас Енерджи» у Високопільському (1 МВт) районах (рис. 1).

Для прогнозування розвитку сучасної енергосистеми альтернативних джерел Херсонської області $\epsilon$ доцільним застосувати картографічні зображення регіону, в яких буде виділено та типізовано адміністративні райони області за двома 


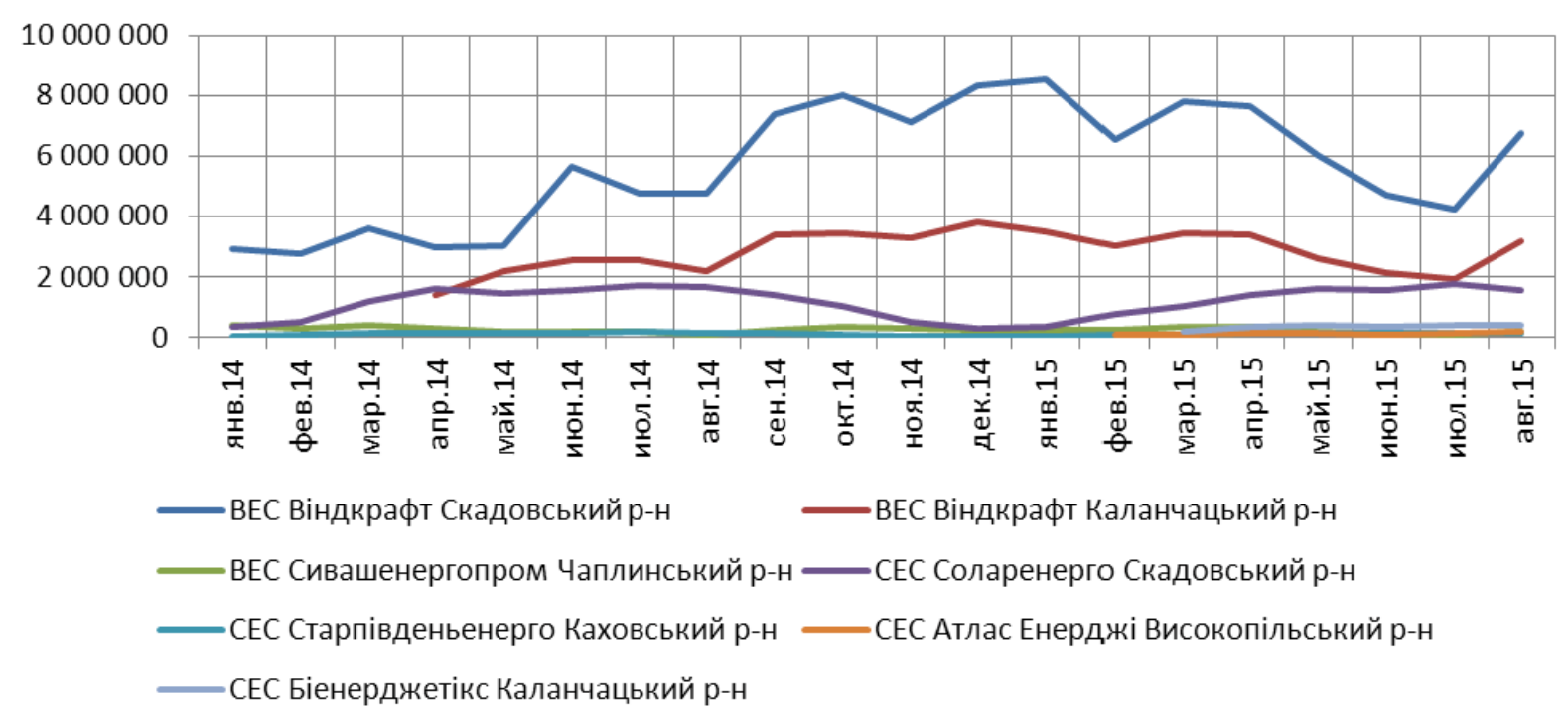

Рис.1. Динаміка виробництва енергії ВЕС та СЕС Херсонської області (складено за матеріалами [8])

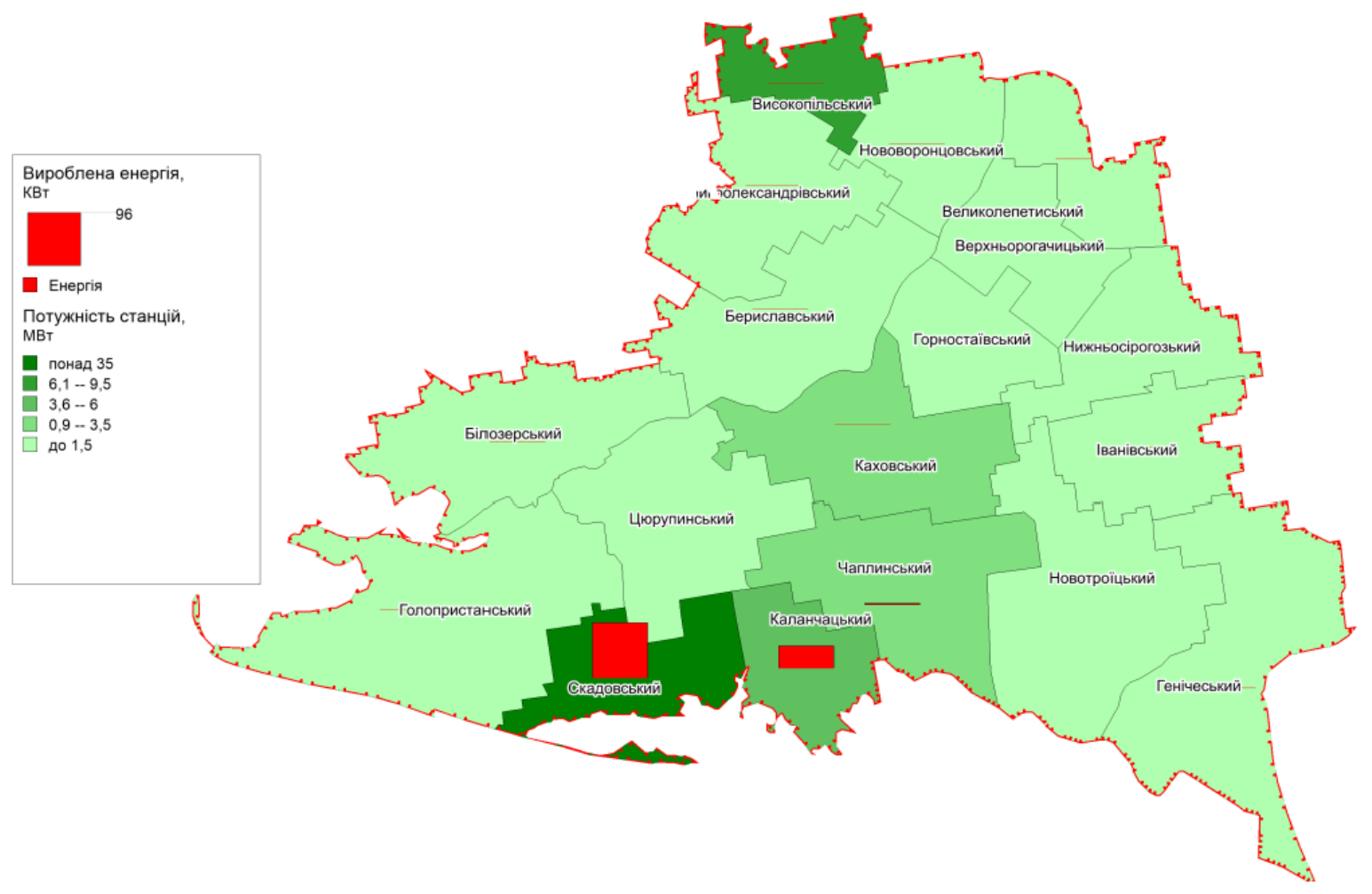

Рис.2. Типізація адміністративних районів Херсонської області

за інтегральним показником розвитку альтернативних джерел енергії (складено за матеріалами [8])

ознаками: загальною потужністю сонячних та вітрових електростанцій і сумарним показником виробленої енергії протягом одного календарного року. Наразі альтернативні джерела енергії представлені лише у п'яти районах: Скадовському, Чаплинському, Каховському, Високопільському i Каланчацькому, - які можна типізувати за інтегральним показником розвитку енергетичних потужностей на такі групи: слабкорозвинені (1-3 МВт) Каховський і Чаплинський райони; середньорозвинені (3-9 МВт) - Каланчацький та Високопільський райони; високорозвинені (більше 9 МВт) Скадовський район. Така типізація пояснюється вдалим географічним положенням Скадовського району біля узбережжя Чорного моря (рис. 2).

Окрім типізації регіонів важливою ознакою $\epsilon$ вплив різних адміністративних районів області на енергетичний баланс та енергосистеми окремого району. Для цього доцільним $є$ побудова поля потенціалу, за яким можна визначити центри, до яких тяжіють інші, енергетично залежні райони (рис. 3).

Iз математично змодельованого зображення можна зробити висновок про моноцентричний тип розподілу енергопотужностей у регіоні: СкадовськоКаланчацький енерговузол $є$ центром постачання енергії для найближчих районів Лівобережжя 


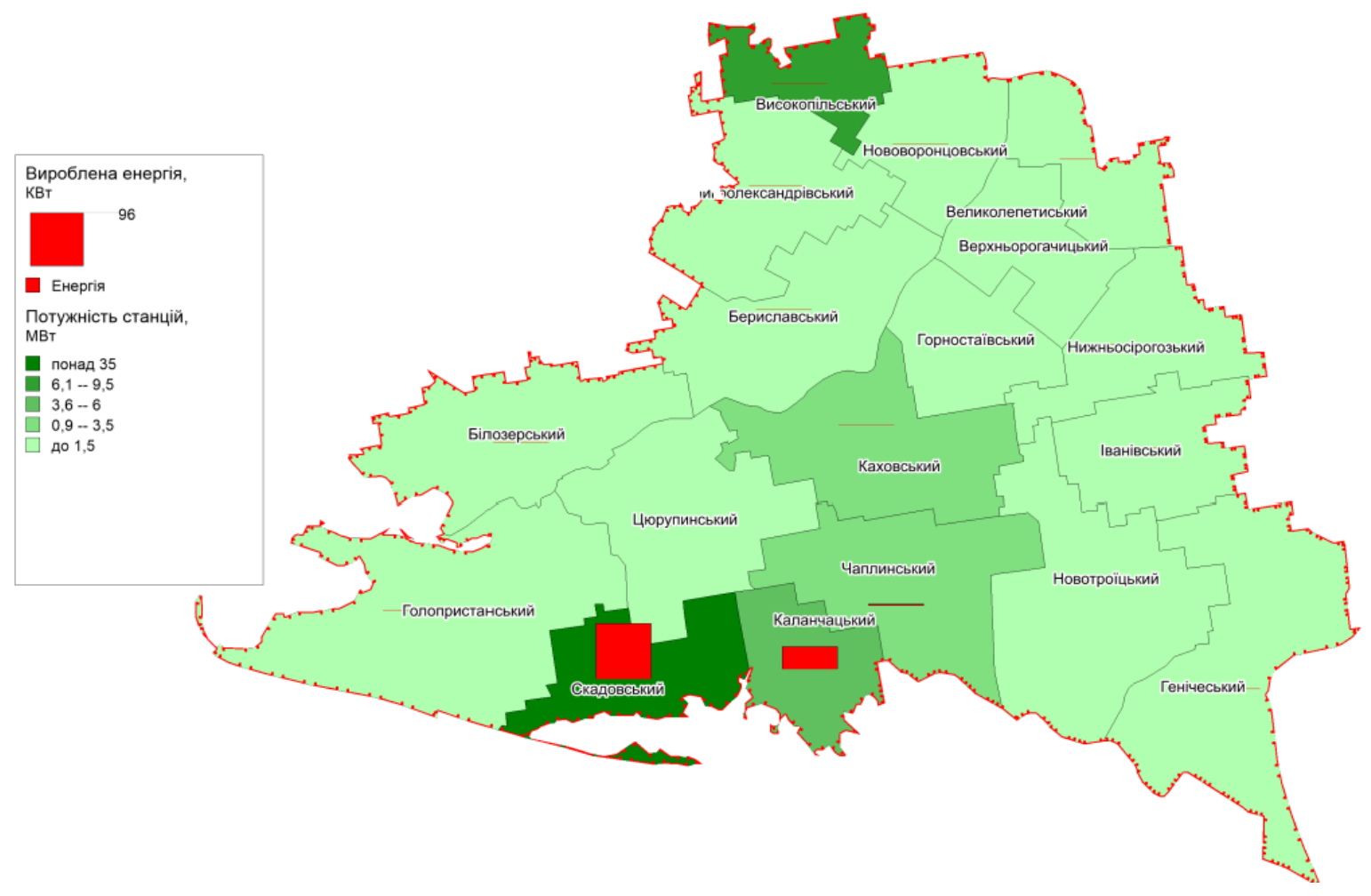

Рис.3. Поле потенціалу потужностей ВЕС і СЕС Херсонської області (складено за матеріалами [8])

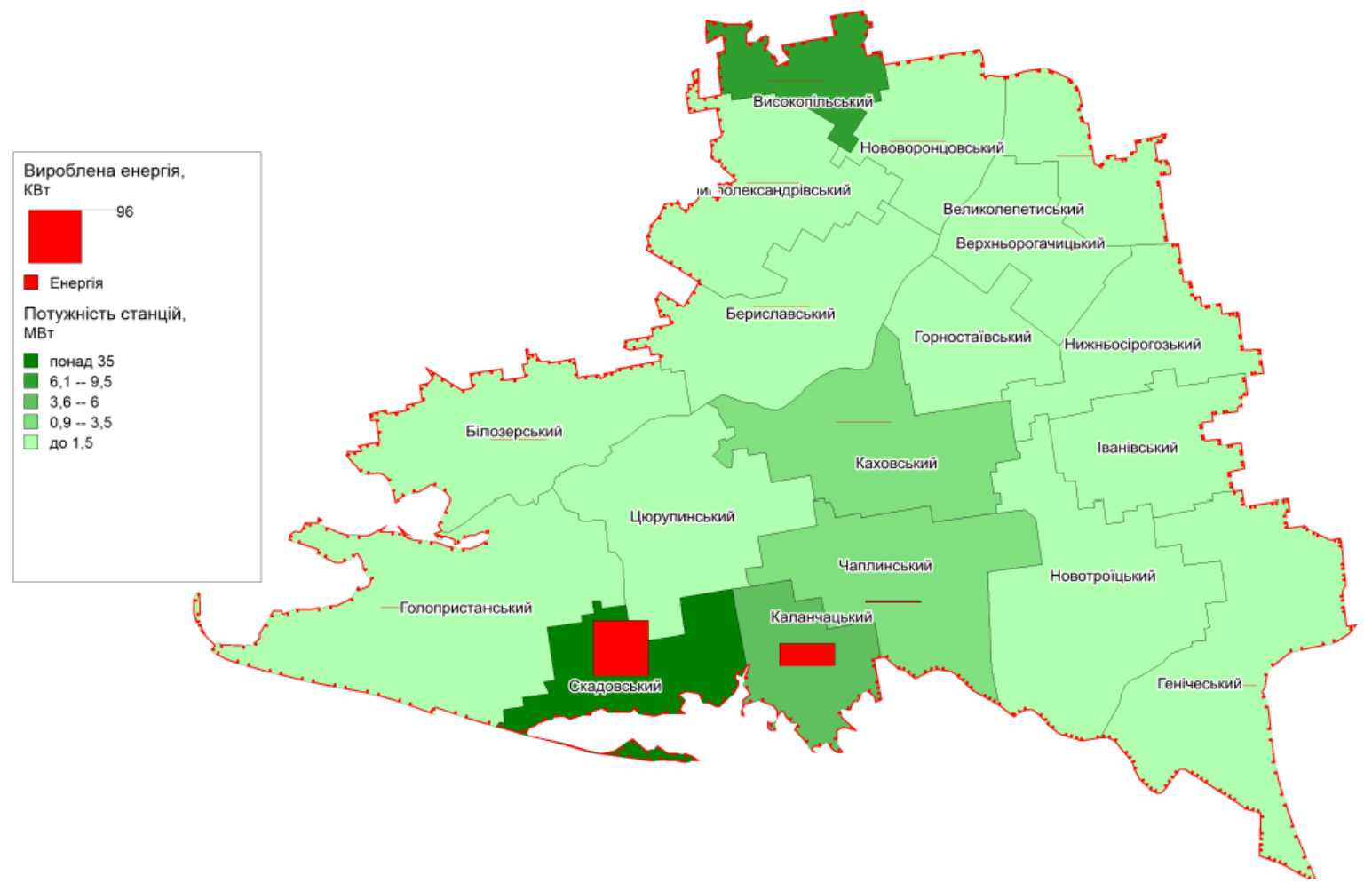

Рис.4. Проектні потужності ВЕС і СЕС Херсонської області (складено за матеріалами [8])

(Чаплинський, Каховський, Голопристанський та Цюрупинський) та усього Правобережжя Дніпра (Білозерський, Великоолександрівський, Нововоронцовський, Високопільський і Херсонська міська рада). Інші райони області, що розташовані на лівому березі Дніпра є периферійними, які залежать від енергії застарілої Каховської ГЕС.
Враховуючи сучасний стан альтернативної енергетики Херсонської області, яка має значний потенціал, є доцільним звернути увагу на подальші зміни в енергосистемі регіону, яка буде детермінувати суспільно-економічні відносини у державі загалом, і на Херсонщині зокрема. Для цього $\epsilon$ необхідність у створенні картосхеми, яка розкриє зміни у енергетичному балансі між районами за 5 
років, що описані у Стратегії розвитку Херсонської області до 2020 року (рис. 4).

Вищеподана картосхема дає змогу побачити прогнозування розвитку альтернативної енергетики, зокрема різке збільшення потужностей Каховського, Новотроїцького, Генічеського та Чаплинського районів. Це викликано вдалим географічним положенням та найменшою щільністю поширення населених пунктів у цих районах.

Оскільки держава не виділяє кошти на спорудження альтернативних енергетичних станцій, то фінансовою основою, на сьогодні, є іноземні інвестиції. Для того, щоб зацікавити потенційних інвесторів вкладати кошти у будівництво $є$ необхідним створення вищезазначених картосхем (рис. 4), які б наглядно показували потенційні можливості розвитку альтернативних джерел енергії на певних територіях.

Висновки i перспективи подалыших розвідок. Таким чином, Херсонська область має значний електроенергетичний потенціал у використанні енергії відновлювальних джерел, а саме енергії Сонця, вітру та переробці біопалива та залученні подальших інвестицій із економічно розвинутих країн Свропи, зокрема таких, як Австрія, Чехія, Словаччина та Франція. Збільшення фінансових надходжень призведе до відновлення електроенергетики Херсонської області, як однієї 3 найбільших галузей промисловості. Збільшення частки електроенергетики у господарському комплексі регіону зробить Херсонщину провідним постачальником теплової й електричної енергії у Причорноморському економічному районі, а в майбутньому - в Україні та за межами держави. Подальші дослідження цієї проблеми будуть спрямовані на математичні розрахунки найідеальнішого розміщення енергетичних станцій з точки зору таких аспектів, як природногеографічний, соціальний, транспортний, економічний і екологічний; можливості впровадження отриманих висновків у практичну діяльність із комерційною метою.

\section{References:}

1. Billij V. S. Programa rozvitku vìdnovlûval'noï energetiki v Hersons'kìj oblastì do 2030 roku (proekt). [Program of renewable energy development in Kherson Region till 2030 (draft)]. 2013, pp. 8-12. (In Ukrainian).

2. Dudčenko O. Al’ternativnì džerela energoresursìv v Ukraïns'komu Pričornomor'ï. Analitična zapiska [Alternative energy sources in the Ukrainian Black Sea Region. Research Note]. Available at: http://www.niss.gov.ua/ articles $/ 232 / \% 29$. (In Ukrainian).

3. Kramarêv G. V. Proektne fìnansuvannâ pri realìzaciï ìnnovacìjnih scenarï̀v rozvitku al'ternativnoï energetiki [Project financing in the implementation of innovative scenarios for the development of alternative energy], Problemi ekonomiki [Problems of economics], 2012, p. 69. (In Ukrainian).

4. L. V. Los', Terlec'kij M. D. Perspektivna al'ternativna energetika [Upcoming alternative energy], Vìsnik ŽNAEU [Bulletin of Zhytomyr National Agroecological University], 2013, N. 1, P. 1, pp. 203-214. (In Ukrainian).

5. Pathways to Sustainable Development and Poverty Eradication. A Synthesis for Policy Makers. UNEP, 2011, p. 2.

6. Polîsuk O. V. Rozvitok al’ternativnoï energetiki v Ukraïnì: stan ta perspektivi rozvitku [Alternative energy in Ukraine: state and prospects of development]. Available at: http://www.er.gov.ua/doc.php?f=2582. (In Ukrainian).

7. Sìvìc'ka S. P. Mì̌narodnij dosvìd ìnvestuvannâ rozvitku al'ternativnoï energetiki [International experience of investing in alternative energy development] Vìsnik ONU ìmenì İ. İ. Mečnikova [Bulletin of the Mechnikov Odessa Nationl University], 2014, T. 19, Vol. 2/2, p. 174. (In Ukrainian).

8. State Enterprise «Energorynok» (official website). Available at: http://www.er.gov.ua/doc.php?f=2612 (In Ukrainian).

9. The Association agreement between Ukraine and the European Union. Available at: http://www.kmu.gov.ua/ $\mathrm{kmu} / \mathrm{control} / \mathrm{ru} / \mathrm{publish} /$ article?art_id=246581344 (In Ukrainian).

10. The law of Ukraine «on alternative energy sources». Vìdomostì Verhovnoï Radi [Bulletin of The Supreme Council], 2003, N 24, p. 155. (In Ukrainian).

11. The law of Ukraine «On electricity». Vìdomostì Verhovnoï Radi [Bulletin Of The Supreme Council], 2013, N 51, p. 714. (In Ukrainian).

12. The law of Ukraine «On Energy Saving». Vìdomostì Verhovnoï Radi [Bulletin of The Supreme Council], 1994, N 30, p. 283. (In Ukrainian).

13. Vasen'ova Û. O., Bikova O. S. Realìzaciâ sistemnih doslìdžen' vìdnovlûval'noï energetiki Hersonŝini v diplomnih proektah [System studies of renewable energy in Kherson region in the graduation projects]. İnformacìjnì tehnologiï v osvìtì, naucì ta virobnictvì [Information technologies in education, science, and production], 2013, Vol. 3(4), pp. 189. (In Ukrainian). 